\title{
Synthesis of new quinoline scaffolds via a solvent-free fusion method and their anti-microbial properties
}

\author{
Sidra Mubeen ${ }^{1 *}$, Abdul Rauf ${ }^{1}$, Ashfaq Mahmood Qureshi ${ }^{2}$ \\ ${ }^{1}$ Department of Chemistry. The Islamia University of Bahawalpur, ${ }^{2}$ Department of Chemistry. The Government Sadiq College \\ Women University, Bahawalpur-63100, Pakistan
}

*For correspondence: Email: lecorganic@yahoo.com, shamashfaq@yahoo.com

\begin{abstract}
Purpose: To develop a robust and simple fusion-based methodology for the synthesis of various 5-(-3nitrophenyl) pyrimido[5,4-c] quinoline-2,4(1H,3H)-diones (5 - 9).

Method: The synthesis involved formation of a Knoevenagel product using barbituric acid and 3nitrobenzaldehyde which cyclized on fusing with various sulfanilamides in a sealed tube at $170-212$ ${ }^{\circ} \mathrm{C}$. This resulted in the synthesis of the target quinolines $(5-9)$. To evaluate their antibacterial and antiviral properties, the synthesized quinolines were tested against four gram-negative bacterial strains and four poultry viruses. The MIC and IC 50 of each active compound were calculated.

Results: Data from NMR, mass spectrometry and elemental analysis confirmed the formation of quinoline scaffolds. Antibacterial screening revealed that all the compounds had antibacterial activities. However, the minimum inhibitory concentration (MIC) of compounds $6-8$ and 9 against Proteus vulgaris and Klebsiella pneumoniae showed that these compounds were more active than the standard drug ampicillin. Antiviral studies and $I C_{50}$ values showed that compounds $5-9$ were effective against Newcastle disease virus (NDV) and infectious bursal disease virus (IBDV), while compounds 5, 6 and 8 were active against avian influenza virus subtype H9N2 (AIV); compounds 7 and 8 were active against infectious bronchitis virus (IBV).

Conclusion: A simple strategy of fusion of Knoevenagel product with aromatic amines can be used to synthesize highly functionalized quinoline scaffolds which are potential drug candidates for development of new antibacterial and antiviral agents.
\end{abstract}

Keywords: Quinoline scaffolds, Barbituric acid, Knoevenagel condensation, Antiviral, Antibacterial

\begin{abstract}
This is an Open Access article that uses a funding model which does not charge readers or their institutions for access and distributed under the terms of the Creative Commons Attribution License (http://creativecommons.org/licenses/by/4.0) and the Budapest Open Access Initiative (http://www.budapestopenaccessinitiative.org/read), which permit unrestricted use, distribution, and reproduction in any medium, provided the original work is properly credited.
\end{abstract}

Tropical Journal of Pharmaceutical Research is indexed by Science Citation Index (SciSearch), Scopus, International Pharmaceutical Abstract, Chemical Abstracts, Embase, Index Copernicus, EBSCO, African Index Medicus, JournalSeek, Journal Citation Reports/Science Edition, Directory of Open Access Journals (DOAJ), African Journal Online, Bioline International, Open-J-Gate and Pharmacy Abstracts

\section{INTRODUCTION}

Quinoline-based compounds show remarkable biological activities. Their heterocyclic scaffold is a fused product of benzene and pyridine (benzopyridine). Heterocyclic scaffolds of quinoline exert potent activities against several diseases [1]. Many clinically accepted drugs such as mefloquine [2], gatifloxacin [3], sitafloxacin [4] and garfenoxacin [5] contain quinoline as their core pharmacophore. The quinoline scaffold is considered a privileged medicinal motif, based on the fact that it is abundant in a number of natural products like alkaloids such as quinine, camptothecin and cinchonidine [6-8]. Quinolines from natural sources have also been used in 
semi-synthesis of drugs. Quinoline derivatives possess pronounced anti-malarial [9], antibiotic [10,11], anti-hypertensive [12], anti-cancer [13], anti-inflammatory [14], anti-HIV [15], anti-fungal [16] and anti-bacterial [17] properties. Moreover, these motifs are antioxidants and possess antiinflammatory and anti-tumor activities [18].

In terms of chemical reactivity, electrophilic substitution is favored by a benzene ring, while nucleophilic substitution is favored by a pyridine ring. Among the different heterocycles, quinolines are the most predominant due to their ease of preparation and stability [18]. The synthetic procedure for quinoline was first reported in the $20^{\text {th }}$ century [19]. Since then, various methods have been developed. These include the synthetic methods of Combes, Conrad-Limpach, Doebner-Miller, Friedlander, Povarov, Camps and Niementowski [20,21]. The applications of quinolines are not limited to biomedicinal purposes. Quinolines have also been used as basic ingredients for the production of different biocides, vermicides, alkaloids, fungicides, rubber chemicals and flavoring agents [22]. Quinoline possesses anti-foaming properties [23] and is used in luminescence chemistry and polymerization reactions [24].

In a view of the importance of quinoline, the current study was focused on the development of five novel quinoline derivatives. Starting with the Knoevenagel product of barbituric acid and aryl aldehydes, further cyclization with various sulfanilamides resulted in the formation of quinoline derivatives. In these reactions, fusion played a vital role. Furthermore, the antiviral and anti-bacterial effects of these quinolone-based heterocycles against four different strains of bacteria and viruses were studied.

\section{EXPERIMENTAL}

\section{General}

All reagents used in this study were purchased from Sigma-Aldrich. Silica gel-coated TLC plates were products of Merck. The mobile phase used was hexane-ethyl acetate in a volume ratio of 2:1, and spots were detected under UV light. The melting points of the compounds were determined using a Gallen Kamp apparatus, while Bruker Spectrophotometer (AVANCE 400) was used for obtaining ${ }^{13} \mathrm{C}$ NMR and ${ }^{1} \mathrm{HNMR}$ spectra at $400 \mathrm{MHz}$. MASPEC system (msw/A091) was used for recording mass spectra. The contents of elements were determined with a CHN analyzer MOD-1106 Carlo Elrba. For Antimicrobial evaluation, four different strains were collected from the bacteriology section of Bahawal Victoria Hospital, and propagated in the biochemistry laboratory at University College of Veterinary and Animal Sciences, Lahore Pakistan. Four different viruses were propagated in chicken embryonated eggs at Islamia University of Bahawalpur, Bahawalpur, Pakistan.

\section{Synthetic procedures}

\section{Production of 5-(3- nitrobenzylidene)pyrimidine-2,4,6(1H,3H,5H)- trione}

Knoevenagel condensation of barbituric acid (1) (10 g,78.07 mmol) with 3-nitrobenzaldehyde (2) (11.79 g, $78.07 \mathrm{mmol})$ using $100 \mathrm{~mL}$ ethanol under reflux for $2 \mathrm{~h}$ yielded 5-(3nitrobenzylidene)pyrimidine-2,4,6(1H,3H,5H)trione (3).

\section{Synthesis of pyrimido[5,4-c] quinoline- 2,4(1H,3H)-diones $(5-9)$}

The general pathway followed for these biologically-active target quinoline molecules was as follows: various 5-(-3-nitrophenyl) pyrimido[5,4-c]quinoline-2,4(1H,3H)-diones $(5-$ 9) were prepared through solvent-free synthetic procedure in a sealed tube at a temperature range of $170-212{ }^{\circ} \mathrm{C}$ using 5-(3nitrobenzylidene)pyrimidine-2,4,6(1H,3H,5H)-

trione (3) $(0.6 \mathrm{~g}, 2.3 \mathrm{mmol})$ with various sulfanilamides $(2.3 \mathrm{mmol})(4)$ for $1-2 \mathrm{~h}$ in an oil bath. On completion of the reaction, the synthesized compounds were assessed for purity using TLC, with hexane-ethyl acetate $(2: 1 \mathrm{v} / \mathrm{v})$ as mobile phase. Washing the synthesized compounds with hot ethanol yielded TLC pure products $(5-9)$. The structures of these target molecules were further confirmed via spectroscopic and spectrometric techniques, and their melting points were determined.

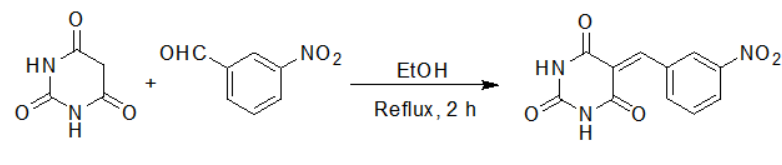

(1)

(2)

(3)

Scheme 1: Synthesis of 5-(3-nitrobenzylidene) pyrimidine-2, 4, $6(1 \mathrm{H}, 3 \mathrm{H}, 5 \mathrm{H})$-trione (3)

\section{Anti-bacterial assay \\ Culturing of bacteria}

Four different gram-negative bacterial strains $(K$. pneumonia, $E$. coli, $P$. vulgaris and $P$. aeruginosa) were used for anti-bacterial evaluation of compounds $5 \mathbf{- 9}$. Sterilized LBbroth $(5 \mathrm{~mL})$ was inoculated with the bacterial 
strains in sterile test tubes and incubated at 37 ${ }^{\circ} \mathrm{C}$ for $16 \mathrm{~h}$ under constant shaking. The $\mathrm{OD}_{600}$ of each overnight grown culture was adjusted to 0.4 which is equal to $0.5 \mathrm{McF}$ arland's standard and $150 \times 10^{6} \mathrm{CFU} / \mathrm{mL}$. A stock solution $(0.1 \mathrm{mg} / \mathrm{mL})$ of each compound (5 - 9) was made in DMSO and used for the antibacterial studies.

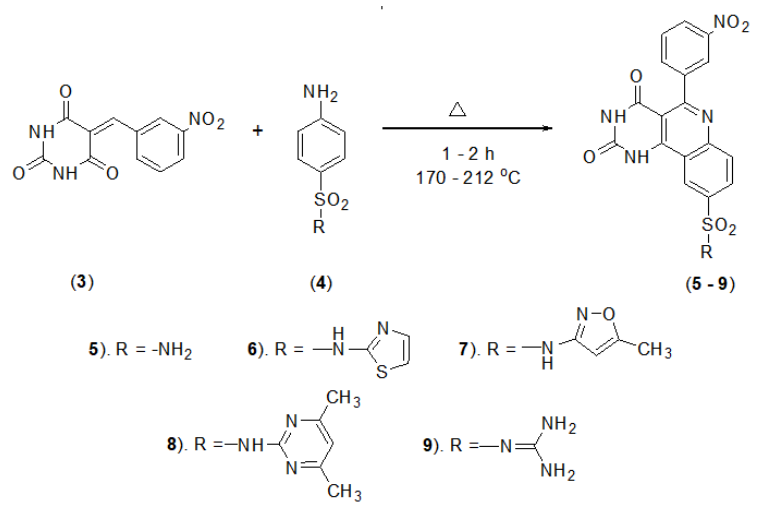

Scheme 2: Steps involved in pyrimido[5,4-c]quinoline2,4(1H,3H)-diones $(5-9)$ synthesis

\section{Disc diffusion method}

Discs were made by cutting 6-mm diameter Whatman filter paper which were then presoaked in the test compounds along with pure solvent i.e. DMSO. Pre-coated discs of ampicillin was used as a positive control. The discs were placed aseptically on seeded plates and incubated at $37 \stackrel{\circ}{\circ}$ overnight. The diameter of zones of inhibition were measured to evaluate the antibacterial effect of each compound (compounds 5 - 9). Furthermore, the MIC of each compound was calculated via a serial dilution method [25].

\section{Anti-viral assessment}

\section{Cultivation of viruses}

All selected viruses i.e. NDV, IBV, BDV and AIV H9N2 strains were subjected to propagation in chicken embryonated (CE) eggs (9 -11 day-old) and incubated in egg incubator at $37^{\circ} \mathrm{C}$. After 48 $h$ of incubation, the allantoic fluids of the eggs were tested for HA (with respect to NDV, AIV, and IBV), and also subjected to IHA test (for IBDV) [26]. Prior to the antiviral assays, the required viral titer (1024 HA) was achieved through serial passage cultures.

\section{Test for hemagglutination (HA)}

Chicken blood was collected in freshly prepared Alsever's medium and the mixture was centrifuged at $4000 \mathrm{rpm}$ for $5 \mathrm{~min}$. The supernatant was discarded and the packed RBCs were washed thrice in $0.1 \mathrm{M}$ phosphate- buffered saline (pH 7.4). A $1 \%$ RBC (working solution) was prepared by diluting the packed RBS in $0.1 \mathrm{M}$ PBS (pH 7.4). The solution was subjected to HA test as described in [27].

\section{Test for indirect hemagglutination (IHA)}

Human blood (type 'O', $3 \mathrm{~mL}$ ) was collected in 4 $\%$ citrate medium, and subjected to centrifugation at $1500 \mathrm{rpm}$ for $5 \mathrm{~min}$. The pelleted cells were washed thrice with 0.1 M PBS $(\mathrm{pH}$ 7.4). The washed cells were added to 1: 2 volume ratio of virus and $0.1 \mathrm{M}$ PBS ( $\mathrm{pH} \mathrm{7.4),} \mathrm{and}$ incubated at $37^{\circ} \mathrm{C}$ for $45 \mathrm{~min}$. The mixture was re-centrifuged at $1500 \mathrm{rpm}$ for $5 \mathrm{~min}$, and the pelleted cells were washed again with $0.1 \mathrm{MPBS}$ ( $\mathrm{pH}$ 7.4). Later the sensitized cells were used to make $1 \%$ suspension in 0.1M PBS ( $\mathrm{pH} 7.4)$. Subsequent procedures were the same as outlined earlier for HA and IHA tests [28,37].

\section{In ovo anti-viral assay}

A stock solution $(0.1 \mathrm{M})$ for each compound (5 9) was prepared in DMSO. Equal volumes of viral inoculum and compound solution (100 $\mu \mathrm{L}$ each) were inoculated in 9 - 11 day-old CE eggs. Amantadine was used as positive control for AIV H9N2 and NDV, while LiCl was used as positive control for IBV and IBDV [29-31]. The HA and IHA titers for the respective viruses were calculated on harvesting allantoic fluids after 48 h.

\section{RESULTS}

\section{Characterization of compounds}

The molecular structures of compounds 5 - 9 were unequivocally determined based on data obtained from ${ }^{1} \mathrm{H},{ }^{13} \mathrm{C}$ NMR, mass spectrometry and elemental analysis.

\section{Spectral data}

Compound 5: 5-(3-nitrophenyl)-2,4-dioxo1,2,3,4-tetrahydropyrimido[5,4-c]quinoline-9sulfonamide

The characteristics of compound 5 were: yield $=$ $60 \%$; yellow solid, decomposed at $>300{ }^{\circ} \mathrm{C},{ }^{1} \mathrm{H}$ NMR $\left(400 \mathrm{MHz}, \mathrm{DMSO}-d_{6}, \delta \mathrm{ppm}, J \mathrm{~Hz}\right): 12.00$ $(1 \mathrm{H}, \mathrm{s}, \mathrm{NH}), 11.41(1 \mathrm{H}, \mathrm{s}, \mathrm{NH}), 8.41(1 \mathrm{H}, \mathrm{dd}, J$ 8.4,1.2), $8.24(1 \mathrm{H}, \mathrm{s}), 8.16(1 \mathrm{H}, \mathrm{dd}, J$ 9.2,2), 8.05 $(1 \mathrm{H}, \mathrm{d}, J$ 9.2), $7.85(1 \mathrm{H}, \mathrm{t}, J$ 8.4), $7.78(1 \mathrm{H}, \mathrm{d}, J$ 7.6), $7.66(1 \mathrm{H}, \mathrm{d}, J 2), 7.47\left(1 \mathrm{H}, \mathrm{s}, \mathrm{NH}_{2}\right) ;{ }^{13} \mathrm{C}$ NMR (100MHz, DMSO-d,$\delta$ ppm): 161.0 (CO), 153.9 (C), 152.9 (C), 150.9 (CO), 149.0 (C), 148.2 (C), 139.0 (C), 136.0 (C), $129.0(\mathrm{CH})$, $128.0(\mathrm{CH}), 128.0(\mathrm{CH}), 128.0(\mathrm{CH}), 127.9$ 
(2CH), $125.4(\mathrm{CH}), 123.0(\mathrm{C}), 109.0(\mathrm{C})$; MS (EI) $\mathrm{m} / \mathrm{z} \% 413.0\left(\mathrm{M}^{+} 100\right): 367.9$ (13), 344.0 (17), 287.1 (18), 215.1 (26), 190.1 (28), 163.1 (4); analytically calculated: $\mathrm{C}, 49.40 ; \mathrm{H}, 2.68 ; \mathrm{N}$, 16.94; found: C, 49.47; H, 2.69; N, 16.91.

\section{Compound 6: 5-(3-nitrophenyl)-2,4-dioxo-N- (thiazol-2-yl)-1,2,3,4-tetrahydropyrimido[5,4- c]quinoline-9-sulfonamide}

Yield $=60 \%$; yellow solid with melting point in the range $280-282{ }^{\circ} \mathrm{C},{ }^{1} \mathrm{H}$ NMR $(400 \mathrm{MHz}$, DMSO- $\left.d_{6}, \delta \mathrm{ppm}, J \mathrm{~Hz}\right): 12.93(1 \mathrm{H}, \mathrm{s}, \mathrm{NH})$, $11.23(1 \mathrm{H}, \mathrm{s}, \mathrm{NH}), 8.07(1 \mathrm{H}, \mathrm{s}), 7.69(3 \mathrm{H}, \mathrm{m})$, $7.60(1 \mathrm{H}, \mathrm{d}, \mathrm{J} 2.4), 7.42(1 \mathrm{H}, \mathrm{d}, \mathrm{J} 8.8), 7.17(1 \mathrm{H}$, dd, J 8.8, 2.4), $6.93(1 \mathrm{H}, \mathrm{s}, \mathrm{NH}), 6.74(1 \mathrm{H}, \mathrm{d}, J$ 8.4), $6.56(1 \mathrm{H}, \mathrm{d}, J 8.4) ;{ }^{13} \mathrm{C}$ NMR (100MHz, DMSO- $d_{6}, \delta$ ppm): 165.0(C), 160.0 (CO), 154.1 (2C), 153.5 (CO), 152.5 (C), $150.3(\mathrm{C}), 138.0$ $(\mathrm{CH}), 137.2(2 \mathrm{C}), 135.1(\mathrm{CH}), 129.0(\mathrm{CH}), 128.1$ $(\mathrm{CH}), 128.2(\mathrm{CH}), 127.5(\mathrm{CH}), 127.0(2 \mathrm{CH})$, $127.6(\mathrm{C}), 126.6(\mathrm{CH}), 117.0(\mathrm{CH}), 112.0(\mathrm{C})$; MS (El) $m / z \% 496.4\left(\mathrm{M}^{+} 15\right): 449.4(13), 412.1(11)$, 334.0 (14), 289.1 (6), 190.1 (14), 128.1 (100). Analitically calculated: $\mathrm{C}, 48.39 ; \mathrm{H}, 2.44 ; \mathrm{N}$, 16.93; found: C, 48.28; H, 2.42; N, 16.90;

Compound 7: N-(5-methylisoxazol-3-yl)-5-(3nitrophenyl)-2,4-dioxo-1,2,3,4tetrahydropyrimido[5,4-c]quinoline-9sulfonamide

Yellow solid with a yield of $55 \%$, and melting point in the range of $294-296{ }^{\circ} \mathrm{C} ;{ }^{1} \mathrm{H}$ NMR (400MHz, DMSO- $d_{6}$, $\delta$ ppm, J Hz): $12.78(1 \mathrm{H}, \mathrm{s}$, $\mathrm{NH}), 10.15(1 \mathrm{H}, \mathrm{s}, \mathrm{NH}), 8.28(1 \mathrm{H}, \mathrm{s}), 8.16(1 \mathrm{H}$, dd, J 7.6, 4.8), $7.83(1 \mathrm{H}, \mathrm{d}, J$ 4.8), $7.57(1 \mathrm{H}, \mathrm{d}, J$ 7.6), $7.44(4 \mathrm{H}, \mathrm{m}), 6.93\left(3 \mathrm{H}, \mathrm{s}, \mathrm{CH}_{3}\right), 6.65(1 \mathrm{H}$, $\mathrm{NH}) ;{ }^{13} \mathrm{C}$ NMR $\left(100 \mathrm{MHz}, \mathrm{DMSO}-d_{6}, \delta \mathrm{ppm}\right)$ : 168.9 (C), 161.1 (CO), 154.0 (C), 153.4 (CO), 152.1 (C), 150.1 (C), 149.9 (C), $133.0(\mathrm{C}), 132.6$ (C), $128.8(\mathrm{CH}), 128.7(\mathrm{CH}), 128.1(\mathrm{CH}), 128.0$ $(\mathrm{CH}), 127.8(\mathrm{CH}), 127.1(\mathrm{CH}), 126.1(\mathrm{C}), 124.2$ $(\mathrm{CH}), 112.0(\mathrm{C}), 92.0(\mathrm{CH}), 12.2\left(\mathrm{CH}_{3}\right)$; MS (El) $\mathrm{m} / \mathrm{z} \% 494.4\left(\mathrm{M}^{+}\right.$13): 448.9 (11), 410.0 (13), 334.0 (13), 289.1 (100), 190.1 (14). Analytically Calculated:: C, 51.01; H, 2.85; N, 17.00; Found: C, $50.91 ; \mathrm{H}, 2.84 ; \mathrm{N}, 17.06$.

\section{Compound 8: N-(4,6-dimethylpyrimidin-2-yl)- 5-(3-nitrophenyl)-2,4-dioxo-1,2,3,4- tetrahydropyrimido[5,4-c]quinoline-9- sulfonamide}

Yield 59\%, Yellow solid, m.p. $298-300{ }^{\circ} \mathrm{C},{ }^{1} \mathrm{H}$ NMR (400MHz, DMSO-d,$\delta$ ppm, $J \mathrm{~Hz}): 12.93$ (1H, s, NH), $11.23(1 \mathrm{H}, \mathrm{s}, \mathrm{NH}), 7.99(1 \mathrm{H}, \mathrm{dd}, J$ 8.4, 3.6), $7.81(1 \mathrm{H}, \mathrm{d}, J 6.0), 7.63(1 \mathrm{H}, \mathrm{d}, \mathrm{J} 8.4)$, $7.40(1 \mathrm{H}, \mathrm{t}, J 8.4), 7.19(1 \mathrm{H}, \mathrm{s}), 7.17(1 \mathrm{H}, \mathrm{d}, J$ 3.6), $7.06(1 \mathrm{H}, \mathrm{s}, \mathrm{NH}), 5.56(2 \mathrm{H}$, dd, J 8.8, 3.2);
${ }^{13} \mathrm{C}$ NMR (100MHz, DMSO-d $\left.d_{6}, \delta \mathrm{ppm}\right): 165.1$ (C), 165.1 (2C), 157.0 (CO), 153.8 (C), 153.3 (CO), 152.1 (C), 150.9 (C), 149.9 (C), 135.1 (C), $134.2(\mathrm{C}), 130.1(\mathrm{CH}), 130.0(\mathrm{CH}), 129.3(\mathrm{CH})$, $127.5(\mathrm{CH}), 127.4(\mathrm{CH}), 124.1(\mathrm{C}), 123.3(\mathrm{CH})$, $110.9(\mathrm{CH}), 108.6(\mathrm{C}), 107.1(\mathrm{CH}), 24.1\left(\mathrm{CH}_{3}\right)$; MS (EI) $m / z \% 519.3\left(\mathrm{M}^{+} 10\right), 435.1$ (11), 390.0 (100), 329.0 (21), 289.1 (12), 213.0 (14), 169.0 (21); analytically calculated: C, 53.18; H, 3.30; N, 18.87; found: C, 53.09; $\mathrm{H}, 3.28$; N, 18.76 .

\section{Compound 9: N-(diaminomethylene)-5-(3- \\ nitrophenyl)-2,4-dioxo-1,2,3,4- tetrahydropyrimido[5,4-c]quinoline-9- sulfonamide}

Yellow solid (yield $=74 \%$ ) that decomposed $>300{ }^{\circ} \mathrm{C}$; ${ }^{1} \mathrm{H}$ NMR $\left(400 \mathrm{MHz}\right.$ DMSO- $d_{6}, \delta \mathrm{ppm}, J$ $\mathrm{Hz}): 11.93(1 \mathrm{H}, \mathrm{s}, \mathrm{NH}), 11.37(1 \mathrm{H}, \mathrm{s}, \mathrm{NH}), 8.41$ (1H, dd, J 8.2), $8.23(1 \mathrm{H}, \mathrm{s}), 8.08(1 \mathrm{H}, \mathrm{dd}, J$ 8.8, 1.6), $7.98(1 \mathrm{H}, \mathrm{d}, J$ 8.8), $7.84(1 \mathrm{H}, \mathrm{t}, \mathrm{J} 8.0), 7.77$ (1H, d, J 8.0), 7.59 (1H, d, J 1.6), $6.67(4 \mathrm{H}, \mathrm{s}$, $\left.2 \mathrm{NH}_{2}\right) ;{ }^{13} \mathrm{C}$ NMR $\left(100 \mathrm{MHz}\right.$, DMSO- $\left.d_{6}, \delta \mathrm{ppm}\right)$ : 160.0 (C), 159.0 (CO), 154.8 (C), 151.2 (C), 150.3 (CO), 149.2 (C), 146.3 (C), 140.7 (C), $135.7(\mathrm{C}), 129.0(\mathrm{CH}), 128.9(\mathrm{CH}), 128.1(\mathrm{CH})$, $127.9(\mathrm{CH}), 126.8(\mathrm{CH}), 124.9(\mathrm{C}), 123.0(2 \mathrm{CH})$, 109.0 (C); MS (EI) $m / z \% 455.3\left(\mathrm{M}^{+} 7\right): 413.1$ (8), 371.0 (10), 301.1 (12), 215.1 (100), 163.1 (14); analytically calculated: $\mathrm{C}, 47.47 ; \mathrm{H}, 2.88 ; \mathrm{N}$, 21.53; found: C, 47.38; H, 2.89; N, 21.50.

Antibacterial and antiviral evaluation of compounds $5-9$

The results of antibacterial assay are shown in Figure 1 (inhibition zones of compounds $\mathbf{5}-\mathbf{9}$ for each bacterial strain) and Table 1 (MIC values of compounds $\mathbf{5} \mathbf{- 9}$ for each bacterial strain). The antiviral activities of compounds $5-9$ are summarized in Table $2 \quad\left(\mathrm{IC}_{50}\right.$ values of compounds which showed antiviral activities).

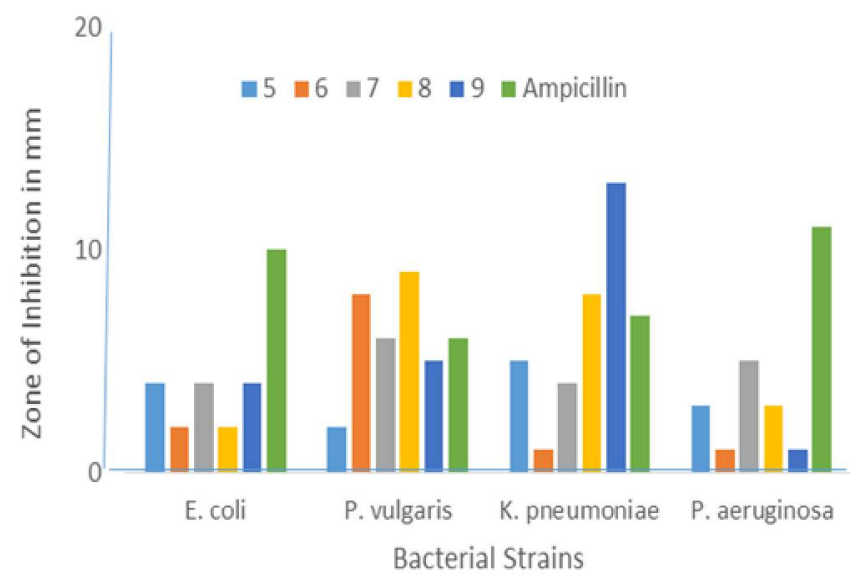

Figure 1: Antibacterial activities of compounds $5-9$ 


\section{DISCUSSION}

In the present study, compounds $\mathbf{5}$ - 9 were synthesized by the combination of barbituric acid, aryl aldehyde and aromatic amines via a twostep reaction sequence. The Knoevenagel condensation of barbituric acid and aryl aldehyde was carried out as described by Zooroh et al [32], resulting in 5-(3nitrobenzylidene)pyrimidine-2,4,6 $(1 \mathrm{H}, 3 \mathrm{H}, 5 \mathrm{H})$ -

trione (3). The trione underwent cyclization through fusion with five different sulfanilamides (4), resulting in five novel quinoline scaffolds (5 9). The yields of the synthesized compounds were appreciable, and they were structurally elucidated through mass spectrometry, elemental composition and NMR data.

Three of the compounds $(6,8,9)$ melted at 180 ${ }^{\circ} \mathrm{C}$, while compounds $\mathbf{5}$ and $\mathbf{7}$ melted at 170 and $212{ }^{\circ} \mathrm{C}$, respectively. All the synthesized compounds were purified through TLC using ethyl acetate: $n$-hexane (2:1 volume ratio) as mobile phase. The zones of inhibition (ZIs) of all five sulfa drugs $(5-9)$ against the four bacterial species revealed that these compounds exhibited antibacterial activities against gramnegative strains. Compounds 6,7 and 8 were more active against Proteus vulgaris (Zls $=6-9$ $\mathrm{mm}$; MICs $=0.5-1.75 \mathrm{mg}$ ), relative to the positive control $(Z I=6 \mathrm{~mm}, \mathrm{MIC}=2.25 \mathrm{mg})$. Similarly, compound $\mathbf{9}$ showed more activity $(\mathrm{Zl}=$ $13 \mathrm{~mm}, \quad \mathrm{MIC}=0.1 \mathrm{mg}$ ) against Klebsiella pneumoniae than the standard drug ampicillin ( $\mathrm{Zl}$ $=7 \mathrm{~mm}$ and $\mathrm{MIC}=1.25 \mathrm{mg}$ ). The Zls of compounds $\mathbf{5}-\mathbf{9}$ suggest that they were mildly active against $E$. coli and $P$. aeruginosa.

Compounds 5 - 9 expressed potential anti-viral properties. Compound $\mathbf{5}$ was highly active against AIV H9N2, NDV and IBDV, while compound 6 was very active against NDV and IBDV, but moderately active against AIV H9N2 and IBV. The lowest $I_{50}(0.001 \mathrm{mg})$ was obtained against AIV H9N2. Compound 7 was active against all the viruses except for AIV $\mathrm{H} 9 \mathrm{~N} 2$; its lowest $\mathrm{IC}_{50}$ value $(0.01 \mathrm{mg})$ was against IBV. Compound 8 showed much higher anti-viral potency than any of the other compounds and was even comparable to the standard antiviral drugs Amantadine and $\mathrm{LiCl}$. It was biologically active against all viruses, and completely inhibited their growth, resulting in zero HA and IHA titers.

Table 1: MIC $(\mathrm{mg} / \mathrm{mL})$ of quinoline scaffolds against bacterial strains

\begin{tabular}{lcccc}
\hline Compound & \multicolumn{4}{c}{ Compounds MIC against bacterial strains $^{*}$} \\
\cline { 2 - 5 } & E. coli & P. vulgaris & P. aeruginosa & K. pneumoniae \\
\hline $\mathbf{5}$ & 25 & 25 & 12.5 & 3.125 \\
$\mathbf{6}$ & 50 & 1.25 & 1.25 & 1.25 \\
$\mathbf{7}$ & 25 & 1.75 & 3.25 & 3.125 \\
$\mathbf{8}$ & 50 & 0.5 & 6.25 & 1.5 \\
$\mathbf{9}$ & 25 & 3.25 & 3.25 & 0.1 \\
Ampicillin & 6.25 & 2.25 & 0.5 & 1.25 \\
\hline
\end{tabular}

Table 2: Antiviral activities of compounds 5-9

\begin{tabular}{|c|c|c|c|c|c|c|c|c|}
\hline Compound & IBV Titer & ${ }^{\star \star} I_{C_{50}}$ & $\begin{array}{c}\text { AIV H9N2 } \\
\text { titer }\end{array}$ & $\mathrm{IC}_{50}$ & $\begin{array}{l}\text { NDV } \\
\text { titer }\end{array}$ & $I_{50}$ & $\begin{array}{c}\text { IBDV } \\
\text { titer }\end{array}$ & $I_{50}$ \\
\hline 5 & 256 & & 0 & 0.001 & 2 & 0.02 & 4 & 0.01 \\
\hline 6 & 64 & & 32 & 0.5 & 4 & 0.05 & 0 & 0.05 \\
\hline 7 & 2 & 0.01 & 512 & -- & 8 & 0.05 & 4 & 0.05 \\
\hline 8 & 0 & 0.05 & 0 & 0.01 & 0 & 0.001 & 0 & 0.001 \\
\hline 9 & 64 & & 1024 & -- & 2 & 0.01 & 4 & 0.01 \\
\hline $\begin{array}{l}\text { *Positive } \\
\text { control }\end{array}$ & 64 & 1.5 & 64 & 0.75 & 64 & 0.5 & 64 & 0.5 \\
\hline $\begin{array}{l}\text { Negative } \\
\text { control }\end{array}$ & 1024 & & 1024 & & 1024 & & 1024 & \\
\hline
\end{tabular}

${ }^{*} \mathrm{LiCl}$ was used as positive control for IB and IBD viruses, while Amantadine was used as positive control for AlH9N2 and ND viruses. ${ }^{* *} I_{50}$ values were calculated by two-fold dilution method. All values are given in $\mathrm{mg} / \mathrm{mL}$

Its lowest $\mathrm{IC}_{50}(0.001 \mathrm{M})$ was recorded against NDV and IBDV. Compound $\mathbf{9}$ was active against NDV and IBDV and slightly active against IBV, but totally inactive against AIV H9N2. It's lowest $\mathrm{IC}_{50}(0.01 \mathrm{mg})$ was recorded against NDV. In addition, compound $\mathbf{9}$ was the least active of all the synthesized compounds.
Antiviral studies of compounds 5 - 9 showed that most of these quinoline drugs were active against NDV and IBDV due to similarities in their structural motifs, except the component sulphonamide. Compound 8 showed broad spectrum antiviral potential due to the attachment 
of 4,6-dimethylpyrimidine ring to sulphonamide moiety. It was active against the four viruses tested. Compounds 5, 6 and $\mathbf{7}$ were next in order. The presence of guanidine moiety in compound 9 made it the least active of all the synthesized compounds.

Studies have revealed that most quinolines are active against gram-negative bacteria [33], Zika virus [34], and tobacco mosaic virus [35]. These findings are in agreement with the results obtained in the present study, which has also shown that substitution on the benzo ring of quinoline significantly influences its biological activity. Thus, although the synthesized compounds had similar core structure, there were variations in their activities due to different sulfonamide group substituents on the benzo ring of quinoline. The high-yielding synthesis of quinoline scaffolds with anti-bacterial and antiviral activities indicates that these compounds can be effective hit candidates for further drug screening studies.

\section{CONCLUSION}

A method for the development of novel 5-(-3nitrophenyl) pyrimido[5,4-c] quinoline$2,4(1 H, 3 H)$-diones with excellent yields and structural confirmation using spectroscopic techniques is reported in this study. The synthesis of quinoline-based compounds i.e. compounds 6 and 8 with MIC or $\mathrm{IC}_{50}$ values comparable to those of the positive control drugs demonstrate that these compounds possess selective and pronounced antibacterial and antiviral potential. Thus, they can be used as viable hits for the development of newer antibacterial and antiviral drug formulations.

\section{DECLARATIONS}

\section{Acknowledgement}

The authors thank the HEC Pakistan, for funding this project. This manuscript was based, in part on the PhD degree thesis of Sidra Mubeen

\section{Conflict of Interest}

No conflict of interest associated with this work.

\section{Contribution of Authors}

The authors declare that this work was done by the authors named in this article and all liabilities pertaining to claims relating to the content of this article will be borne by them.

\section{REFERENCES}

1. Park DY, Lauwers GY. Gastric polyps: classification and management. Arch Pathol Lab Med 2008; 132: 633-640.

2. Kim YH, Kim NG, Lim JG, Park C, Kim H. Chromosomal Alterations in Paired Gastric Adenomas and Carcinomas. Am J Pathol 2001; 158: 655-662.

3. Carmack SW, Genta RM, Schuler CM, Saboorian MH. The current spectrum of gastric polyps: a 1-year national study of over 120,000 patients. Am J Gastroenterol 2009; 104: 1524-1532.

4. Goddard AF, Badreldin R, Pritchard DM, Walker MM, Warren $B$. The management of gastric polyps. Gut 2010; 59: 1270-1276.

5. Qin $F$, Huang $X$, Ren $P$. Chinese herbal medicine modified xiaoyao san for functional dyspepsia: Meta-analysis of randomized controlled trials. $J$ Gastroenterol Hepatol 2009; 24: 1320-1325.

6. Xiao Y, Liu Yy, Yu Kq, Ouyang Mz, Luo $R$, Zhao Xs. Chinese herbal medicine liu jun zi tang and xiang sha liu jun zi tang for functional dyspepsia: meta-analysis of randomized controlled trials. Evid Based Complement Alternat Med 2012; 2012.

7. Singhuber J, Zhu M, Prinz S, Kopp B. Aconitum in traditional Chinese medicine: $A$ valuable drug or an unpredictable risk? J Ethnopharmacol 2009; 126: 18-30.

8. Gu Y, Zhang $Y$, Shi X, Li X, Hong J, Chen J, Gu W, Lu X, $X u$ G, Ning G. Effect of traditional Chinese medicine berberine on type 2 diabetes based on comprehensive metabonomics. Talanta 2010; 81: 766-772.

9. Tian L. Shen-ling-bai-zhu decoction scattered flavored rhubarb protect the intestinal mucosal barrier function of experimental research. Med J Liaoning 2011; 01: 9-11.

10. Xi S, Peng Y, Minuk GY, Shi M, Fu B, Yang J, Li Q, Gong $Y$, Yue $L, L i L$ et al. The combination effects of ShenLing-Bai-Zhu on promoting apoptosis of transplanted H22 hepatocellular carcinoma in mice receiving chemotherapy. J Ethnopharmacol 2016; 190: 1-12.

11. Jia Taiyuan BHS. Dangshen for $J 774$ rat effect of the activity of macrophage cell. Lishizhen Med Mater Med Res 2010; 11: 769-770.

12. Wangruina. The pharmacological effects and the comprehensive development and utilization of medicinal atractylodes. Anhui Ag Sci 2010; 38: 5610-5611, 5627.

13. $W u Y$, Yuan $Y$. Advance in studies on chemical components and pharmacological effect of Semen Coicis. West Pharm J 2010; 25: 111-113.

14. Lu J, Cai J, Dai Y. Research progress of Semen Dolichoris Album. Hubei J TCM 2013; 35: 77-79. 